\title{
Identification of Fungi and Detection of Mycotoxins Associated with Infected Fig Fruits
}

\author{
Eman H. Attaalla ${ }^{1}$; Heba M. Abdel-Nabi ${ }^{2 *}$; Nadia M. Awany ${ }^{1}$ and Laila F. Hagagg ${ }^{3}$ \\ ${ }^{1}$ Department of Botany, Faculty of Science, Zagazig University, Zagazig, Egypt \\ ${ }^{2}$ Department of Agricultural Botany, Faculty of Agriculture, Suez Canal University, Ismailia, 41522, Egypt \\ ${ }^{3}$ Department of Pomology, National Research Center, Giza, Egypt
}

Received: $26 / 2 / 2018$

\begin{abstract}
The aim of this research is to isolate and identify the fungi associated with infected fig fruits in different Governorates in Egypt (Alexandria, Qalubia, Ismailia, Giza and Sinai), as well as study their ability to produce aflatoxins. Samples of fresh fig fruits were collected, small slices of peel were disinfected and transferred to Petri-dishes containing PDA medium and incubated at $25^{\circ} \mathrm{C}$ for 5 days. The higher total fungal counts as 201,111 and 102 isolates were recorded on the samples from Qalubia, Sinai and Ismailia, respectively and the least as 48 isolates was found on samples from Giza. Seven fungal genera were identified (Alternaria tenuis, Aspergillus flavus, A. niger, A. parasiticus, A. terreus, Botryodiplodia theobromae, Cladosporium sp., Fusarium solani, Penicillium sp. and Rhizopus sp.). All Aspergillus genera produced mycotoxins except Aspergillus terreus which was negative producer of mycotoxins (AFB ${ }_{1}$, $\mathrm{AFB}_{2}, \mathrm{AFG}_{1}$ and $\mathrm{AFG}_{2}$ ).
\end{abstract}

Keywords: Aflatoxins, Aspergillus, figs, fungi, mycotoins

\section{INTRODUCTION}

Edible figs (Ficus carica L.) is a deciduous tree or shrub belonging to the Moraceae family and native to Asia Minor, from where it spread into the Mediterranean regions.

The fig is a nutritious fruit, rich in fibers, potassium, calcium, iron and is free of sodium, fat and cholesterol (Stover et al., 2007). Additionally, figs are an important source of vitamins, amino acids and antioxidants (Solomon et al., 2006).

In Egypt, figs are widely grown in North West Coast and North Sinai and the total cultivated area is about 69865 Acer. Egypt is the second largest producer of fig worldwide after Turkey with annual production of 176.105 tons per year according to FAOSTAT (2014).

Fungal infection of the fig fruits may occur during the growing season, harvesting, handling, transport and post-harvest storage and marketing conditions. The fig fruits contain high levels of sugars, nutrients, and with low $\mathrm{pH}$ the fruits are vulnerable to fungal decaying (Singh and Sharma, 2007). About $70 \%$ of crop diseases were due to fungi causing high economic losses, major crop disease and postharvest losses of agriculture products (Agrios, 2005).

The problem of fig fruits is the developing of fungal decay inside the fig fruits; furthermore ostiole size seems to be correlated with the incidence of fungal decay and with poor quality of fruit (Ferguson et al., 1990).

Doster and Michailides (2007) and Coviello et al. (2009) reported that the major fruit disease affecting figs are smut in dried fruits caused by Aspergillus niger, Alternaria rot caused by (Alternaria alternate or other Alternaria spp. and often associated with other fungi such as Cladosporium herbarum or Ulocladium atrum), gray mold or Botrytis rot (caused by Botrytis cinerea), fig endosepsis (caused by Fusarium moniliforme and other Fusarium spp.) and sour rot or souring (caused by various yeasts and bacteria including species in the genus Hanseniaspora, Saccharomyces, Pichia or Bacilli). They also found that Aspergillus flavus and $A$. parasiticus can produce the mycotoxins known as aflatoxin.

Sekar et al. (2008) identified Aspergillus flavus, A. niger, Rhizopus sp., Mucor sp. and Penicillium sp. from different samples of figs, maize, dates and grapes which collected from storage shops.

Bhale (2011) stated that the common postharvest and storage fungi of fig fruits are Alternaria spp., Aspergillus spp., Fusarium spp. and Penicillium spp.

Embaby et al. (2012) isolated 140 isolates from fresh figs and 80 isolates from dried figs. Five fungal genera were identified i.e. Alternaria, Aspergillus, Fusarium, Mucor and Rhizopus from fresh and dried figs. Some isolates of Aspergillus were positive producer of aflatoxins while the others were negative producer.

Saadullah and Abdullah (2014) collected samples from four types of dried fruits (apricot, fig, grapes and plum). A total of 20 species of Aspergillus were isolated on Dichloran Rose Bengal Chloramphenicol Agar medium (DRBC medium). Aspergillus awamori, A. carbonarius, $A$. flavus, $A$. fumigatus, $A$. japonicas, $A$. niger, $A$. ochraceus, $A$. parasiticus and A. tubingensis were detected from all types of dried fruits.

Farjood and Banhashemi (2013) isolated 24 Aspergillus species from soil, leaf and fig fruit samples. The Aspergillus species percentages were A. alliaceus (3.13), A. carbonarius (7.44), A. 
flavus (35.1), A. fumigatus (6.38), A. japonicus (2.13) and A. terreus (2.13).

The present research aims to isolate and identify the fungi associated with fig fruits in different regions in Egypt, as well as study their ability to produce aflatoxins.

\section{MATERIALS AND METHODS}

This work was carried out during the seasons 2015-2017 at the Laboratory of Plant Pathology, Department of Agricultural Botany, Faculty of Agriculture, Suez Canal University.

Samples of fresh fig fruits (Ficus carica L.) were collected from Alexandria, Giza, Ismailia, Qalubia, and Sinai Governorates in Egypt, put into sterile polyethylene bags. Date and place of samples collections were recorded, and then the bags were sealed properly and brought into the laboratory of plant pathology for further studies.

Fig fruits were washed with tap water followed by sterile distilled water several times. Then they were surface sterilized by dipping in $1 \%$ sodium hypochloride $(\mathrm{NaOCl})$ for 2 min., after that, the fruits were washed twice with sterile distilled water. Small slices of peel from sterilized fruits were again disinfected with $0.5 \% \mathrm{NaOCl}$ for $1 \mathrm{~min}$, followed by rinsing with sterile distilled water and dried on sterilized filter papers. The slices were transferred to Petri-dishes containing Potato Dextrose Agar medium (PDA) and incubated at $25^{\circ} \mathrm{C}$ for 5 days. Fungal growth on fruits were isolated and purified on PDA slant.

All fungal isolates (7-14 days old) were identified in Plant Pathology Dept., Faculty of Agriculture, Suez Canal University, based on cultural and morphological characteristics on specific PDA medium according to Maren and Johan (1988) for genus Aspergillus, Nelson et al. (1983) for Fusarium, and Barent and Hunter (1977) for the genera of imperfect fungi, Singh et al. (1991) for either Aspergilli, Fusaria, and Penicillia, Samson and Varga (2007), Watanabe (2010), Oranusi and Wesley (2012), Agwa et al. (2014) and El-Fadaly et al. (2015).

All identified fungi were cultured on PDA slants (Tournas and Katsoudas, 2005) and stored at $4^{\circ} \mathrm{C}$ until used. Total fungal counted and frequency percent of naturally occurred fungi in fruit samples were calculated.

\section{Mycotoxin analysis:}

Samples of fresh fig fruits were prepared according to the method described by (AOAC, 2007) in Food Toxicology and Contamination Dept. National Research Center (NRC) for detection of aflatoxins (AFs).

To prepare spore suspension, spores from colonies (6-10 days old) of Aspergillus flavus, Aspergillus niger, Aspergillus parasiticus, and Aspergillus terreus were collected by adding $5 \mathrm{ml}$ of sterile distilled water to each Petri dish containing spores and rubbing the surface with a sterile L-shaped spreader (3 times). The suspension was collected and then centrifuged at room temperature (Tzortzakis, 2009). The suspension was diluted with the sterile water to obtain the spore suspension $\left(10^{5}\right.$ spores $\left./ \mathrm{ml}\right)$.

Mycotoxins were detected using $100 \mathrm{~g}$ of fig fruits which were surface sterilized with $70 \%$ ethanol and then wounded. Five microliters of the spore suspension at $10^{5} \mathrm{CFU} / \mathrm{ml}$ were injected into each wound then incubated at $26^{\circ} \mathrm{C}$ for 15 days.

Aflatoxins AFB1, AFB2, AFG1 and AFG2 were determined in artificially inoculated fig fruits using High Performance Liquid Chromatography (HPLC) according to (AOAC, 2007).

The HPLC instrument used for aflatoxins determination was waters (474) system, equipped with the quaternary pump fluorescence detector set system at $360 \mathrm{~nm}$ excitation and $440 \mathrm{~nm}$ emission wave lengths. The chromatography column was phenomenex c18 (250 x $4.6 \mathrm{~mm}), 5$ $\mu \mathrm{m}$. The mobile phase was water: methanol: acetonitrile $\left.\quad\left(\mathrm{H}_{2} \mathrm{O}: \quad \mathrm{MeOH}: \quad \mathrm{CH}_{3} \mathrm{CN}\right) \quad 3: 1: 1 \mathrm{v} / \mathrm{v} / \mathrm{v}\right)$ was isocratically at a flow rate of $1 \mathrm{ml} / \mathrm{min}$ (Han et al., 2004).

Data were collected and integrated using Total Chrome Navigator Chromatography Manager Software.

\section{RESULTS AND DISCUSSION}

Isolation and Identification of Fungi:

Data in Figure (1) showed that, fig fruit samples from Qalubia area gave the highest total fungal count as 201 isolates of fungi equal $37.43 \%$ comparing with other governorates. Sinai samples produced 111 isolates equal $20.67 \%$ then, Ismailia samples which recorded 102 isolates of fungi equal $18.99 \%$. The least total fungal isolates with 48 isolates equal $8.94 \%$ was found on the fig fruit samples from Giza.

\section{Fungal frequency:}

The fungal frequency detected with rotted fig fruits samples from the different governorates in Egypt is presented in Table (1). The fungal species which belong to seven genera were identified. These were Alternaria tenuis, Aspergillus flavus, Aspergillus niger, Aspergillus parasiticus, Aspergillus terreus, Botryodiplodia theobromae, Cladosporium sp., Fusarium solani, Penicillium sp. and Rhizopus sp. (Figures 2-8).

Also, data showed that, the genus Aspergillus was the most frequently isolated fungus with 303 isolates. Eighteen of these isolates $(3.35 \%)$ for Aspergillus flavus, 186 isolates (34.64\%) for Aspergillus niger, 81 isolates (15.08\%) for Aspergillus parasiticus and 18 isolates (3.35\%) for Aspergillus terreus.

The detected fungi which followed genus Aspergillus were Rhizopus sp. which recorded 63 isolates (11.73\%), Penicillium sp. 45 isolates 
(8.38\%), Cladosporium sp. 42 isolates (7.82\%), Alternaria tenuis 36 isolates $(6.70 \%)$, Fusarium solani 36 isolates $(6.70 \%)$ and Botryodiplodia theobromae was the fungal species occurred with 12 isolates $(2.23 \%)$.
Briefly, data showed that Aspergillus niger was the higher fungal frequency (34.64\%) associated with fig fruits samples. Whereas, Botryodiplodia theobromae was the lowest fungal frequency $(2.23 \%)$ followed by Aspergillus flavus and Aspergillus terreus (3.35\%).

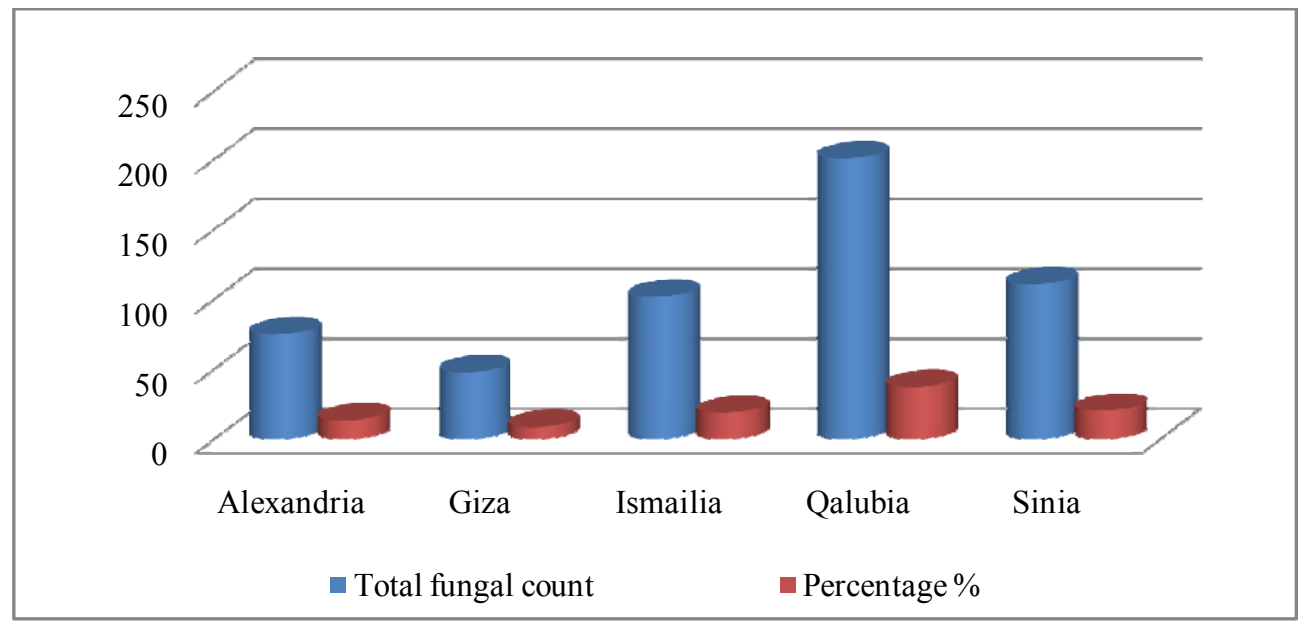

Fig. (1): Total count and percentages of fungi associated with rotted fig fruits from different governorates in Egypt

Table (1): Fugal frequency associated with rotted fig fruits from different governorates in Egypt

\begin{tabular}{|c|c|c|c|c|c|c|c|c|c|c|c|c|}
\hline \multirow{3}{*}{ Fungal isolates } & \multicolumn{10}{|c|}{ Governorates } & \multirow{2}{*}{\multicolumn{2}{|c|}{ Total }} \\
\hline & \multicolumn{2}{|c|}{ Alexandria } & \multicolumn{2}{|c|}{ Giza } & \multicolumn{2}{|c|}{ Ismailia } & \multicolumn{2}{|c|}{ Qalubia } & \multicolumn{2}{|c|}{ Sinai } & & \\
\hline & T.C.F & $\%$ & T.C.F & $\%$ & T.C.F & $\%$ & T.C.F & $\%$ & T.C.F & $\%$ & T.C.F & $\%$ \\
\hline Alternaria tenuis & ND & 0.00 & 9.00 & 1.68 & 9.00 & 1.68 & ND & 0.00 & 18.00 & 3.35 & 36.00 & 6.70 \\
\hline Aspergillus flavus & 3.00 & 0.56 & ND & 0.00 & 9.00 & 1.68 & 3.00 & 0.56 & 3.00 & 0.56 & 18.00 & 3.35 \\
\hline Aspergillus niger & 18.00 & 3.35 & 18.00 & 3.35 & 30.00 & 5.59 & 75.00 & 13.97 & 45.00 & 8.38 & 186.00 & 34.64 \\
\hline $\begin{array}{l}\text { Aspergillus } \\
\text { parasiticus }\end{array}$ & 9.00 & 1.68 & 9.00 & 1.68 & 15.00 & 2.79 & 30.00 & 5.59 & 18.00 & 3.35 & 81.00 & 15.08 \\
\hline Aspergillus terreus & ND & 0.00 & ND & 0.00 & 3.00 & 0.56 & 15.00 & 2.79 & ND & 0.00 & 18.00 & 3.35 \\
\hline $\begin{array}{l}\text { Botryodiplodia } \\
\text { theobromae }\end{array}$ & 3.00 & 0.56 & ND & 0.00 & ND & 0.00 & 9.00 & 1.68 & ND & 0.00 & 12.00 & 2.23 \\
\hline Cladosporium sp. & 30.00 & 5.59 & ND & 0.00 & ND & 0.00 & 12.00 & 2.23 & ND & 0.00 & 42.00 & 7.82 \\
\hline $\begin{array}{l}\text { Fusarium } \\
\text { Solani }\end{array}$ & 3.00 & 0.56 & 3.00 & 0.56 & 3.00 & 0.56 & 18.00 & 3.35 & 9.00 & 1.68 & 36.00 & 6.70 \\
\hline Penicillum sp. & ND & 0.00 & ND & 0.00 & 18.00 & 3.35 & 18.00 & 3.35 & 9.00 & 1.68 & 45.00 & 8.38 \\
\hline Rhizopus sp. & 9.00 & 1.68 & 9.00 & 1.68 & 15.00 & 2.79 & 21.00 & 3.91 & 9.00 & 1.68 & 63.00 & 11.73 \\
\hline Total & 75.00 & 13.97 & 48.00 & 8.94 & 102.0 & 18.99 & 201.00 & 37.43 & 111.0 & 20.67 & 537.00 & 100.0 \\
\hline
\end{tabular}

These results were in agreement with Embaby et al. (2012) who isolated 140 isolates from fresh figs and 80 isolates from dried figs. Five fungal genera were identified as Alternaria, Aspergillus, Fusarium, Mucor and Rhizopus from fresh and dried figs. Some isolates of Aspergillus were positive producer of aflatoxins, while the others were negative producer. Embaby et al. (2014) isolated Alternaria citri, Botryodiplodia theobromae, Fusarium sp., Penicillium digitatum and Penicillium italicum from citrus fruits and reported that the genus Penicillium had the most isolation frequency from both Behira and Qalyoubia governorates in Egypt.

In the present study, results revealed that Aspergillus niger was the most frequently isolated fungal species (34.64\%) followed by $A$. parasiticus by $(15.08 \%)$, whereas $A$. flavus and $A$. terreus by $(3.35 \%)$ for each. This is in line with data presented by Saadullah and Abdullah (2014) who found that the most fungal species isolated from figs were $A$. niger followed by $A$. flavus, $A$. carbonarius and $A$. parasiticus with a percentage 
frequencies of $76.65 \%, 66.6 \%, 33.1 \%$ and $33.1 \%$, respectively.

Aspergillus flavus and $A$. niger were reported as being the most common species on dried figs, Pitt and Hocking (2009). Also Embaby et al. (2012) noted that A. niger, A. flavus and $A$. parasiticus were the most frequent species on dried figs in Egypt. Similar results were reported by Doster et al. (1996) from figs in California.
Javanmard (2010) found that the most frequently isolated species from Iranian figs was $A$. niger aggregate $(90 \%)$ followed by $A$. flavus $(63.76 \%)$.

To explain these results, high incidence of black Aspergillus can be referred to their black spores that can provide protection from sunlight and ultraviolet light, giving them competitive advantages, these fungi are xerophilic, thus can tolerant high sugar concentrations and low water activity (Iamanaka et al., 2005).

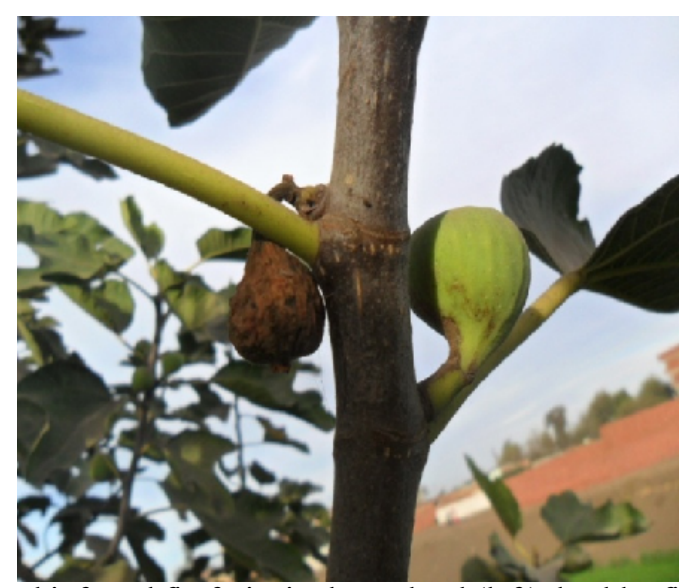

Fig. (2): Natural infected fig fruits in the orchard (left); healthy fig fruits (right)

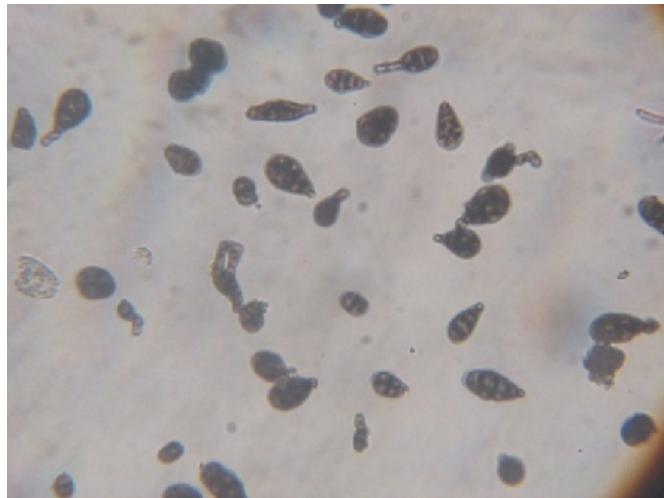

Fig. (3): Alternaria spores under light microscope

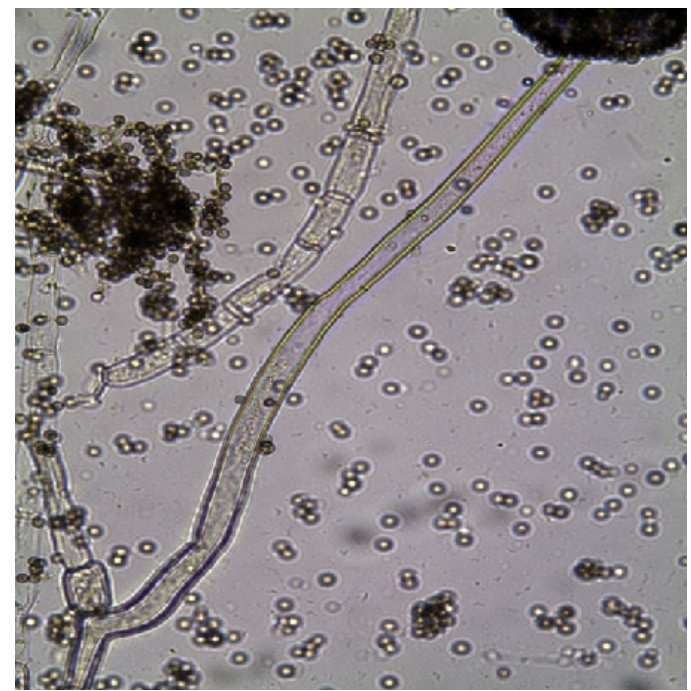

Fig. (4): Aspergillus sp. under light microscope 


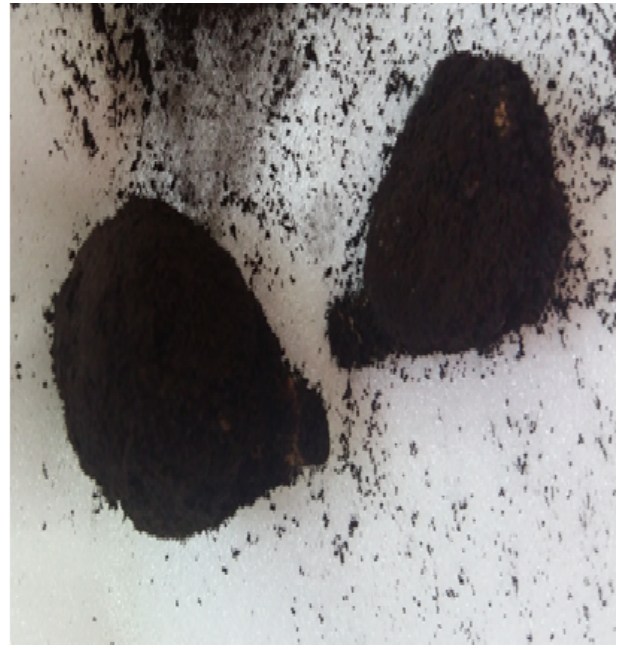

Fig.(5): Fig fruits infected with Aspergillus niger

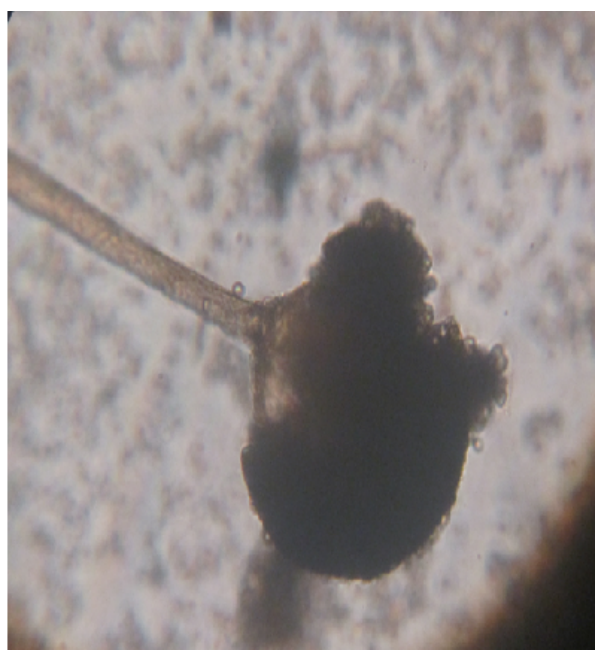

Fig.(6): Aspergillus niger under light microscope

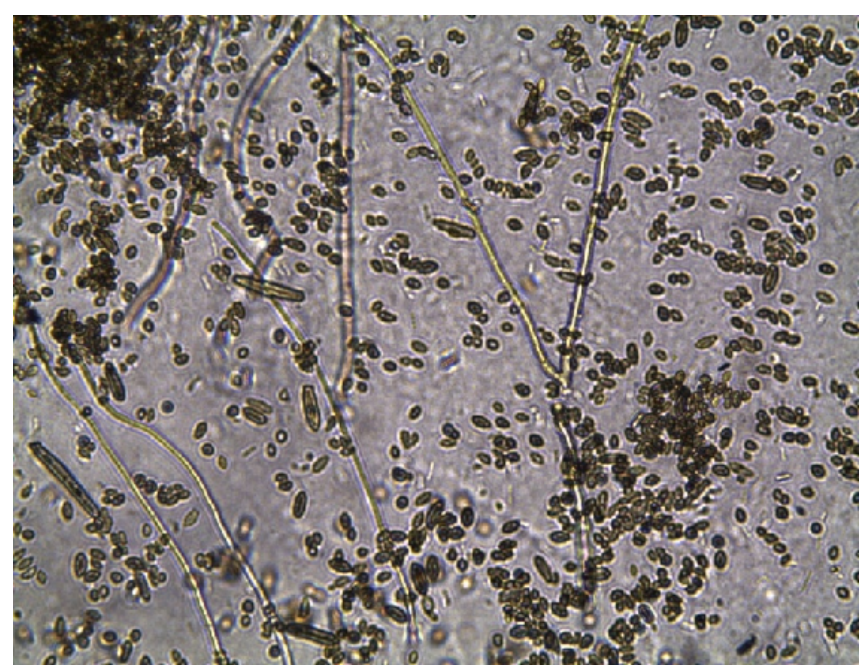

Fig. (7): Botryodiplodia spores under light microscope

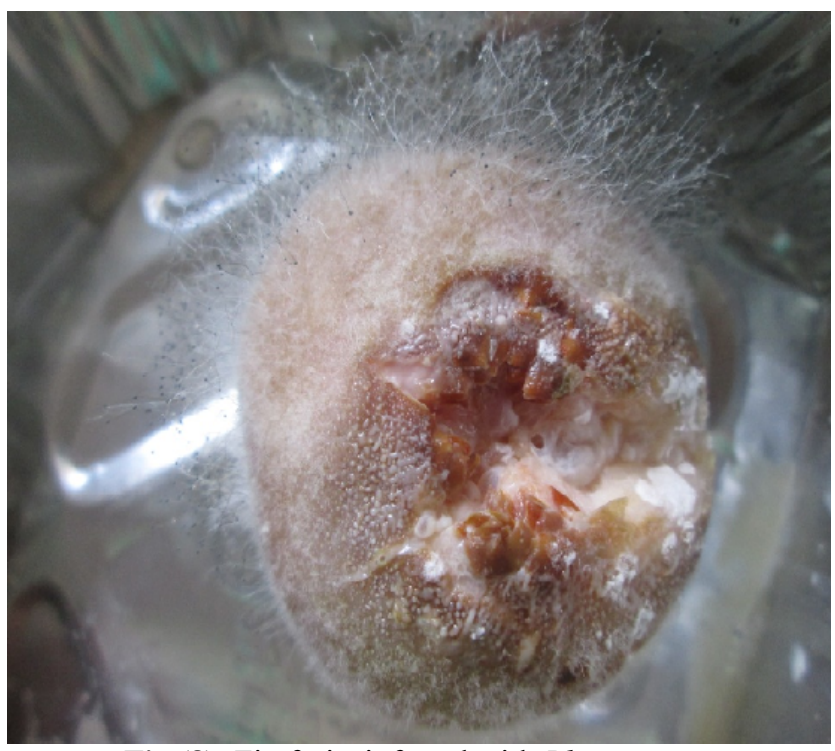

Fig.(8): Fig fruits infected with Rhizopus sp. 
Mycotoxin production by Aspergillus genera

Aspergillus flavus, Aspergillus niger, Aspergillus parasiticus and Aspergillus terreus were tested using thin layer chromatography (TLC) for production of mycotoxins.

Identification of aflatoxins could easily be deduced from the constant retention time compared with the standard spiked in the HPLC chromatogram. In this regard, Figure (9) showed the standard curve of Mycotoxin production of Aflatoxin (AFB1, AFB2, AFG1 and AFG2), while Figures (10, 11, 12 and 13) presented the Aflatoxins produced by Aspergillus flavus, Aspergillus niger, Aspergillus parasiticus and Aspergillus terreus, respectively.

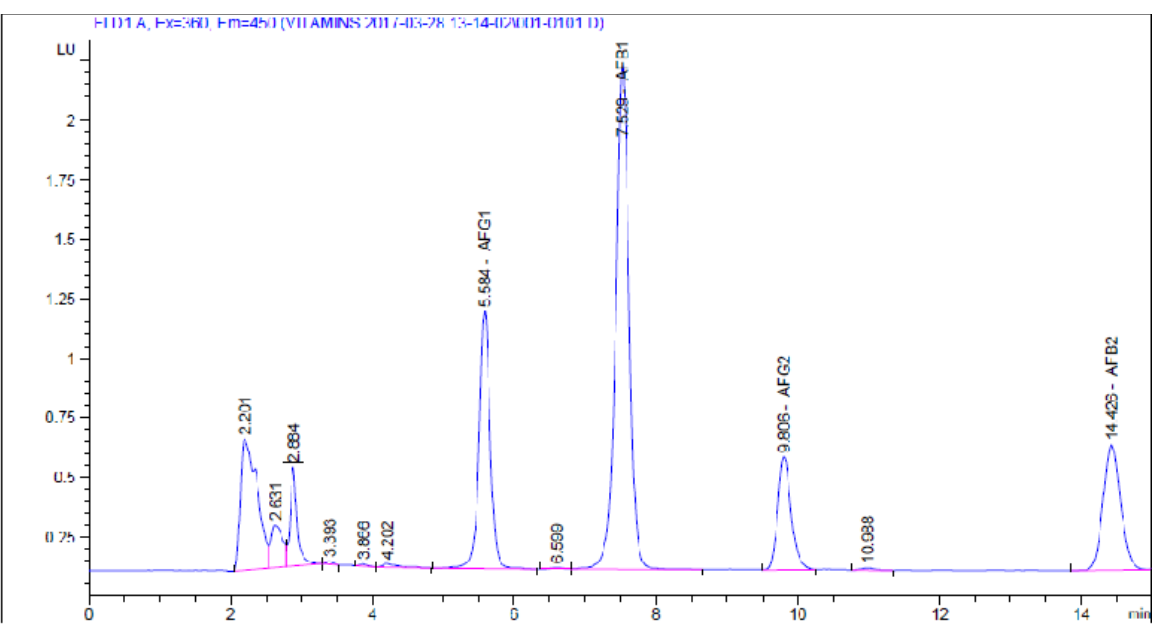

Fig. (9): Standard curve of Mycotoxin production of Aflatoxins $\left(\mathrm{AFB}_{1}, \mathrm{AFB}_{2}, \mathrm{AFG}_{1}\right.$ and $\left.\mathrm{AFG}_{2}\right)$

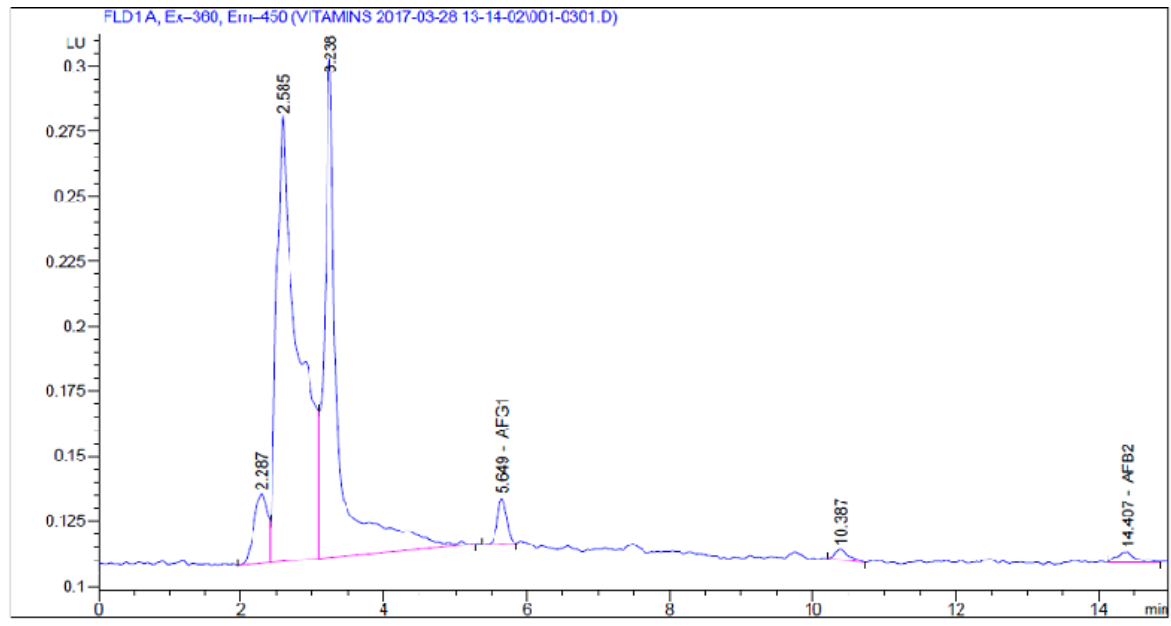

Fig. (10): Aflatoxins produced by Aspergillus flavus

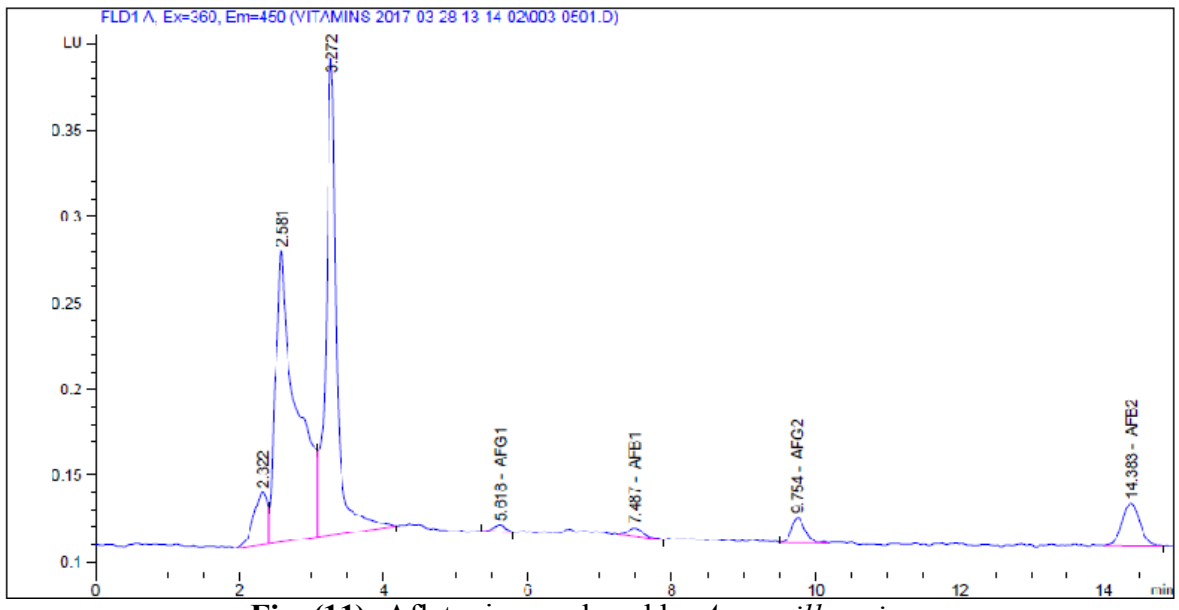

Fig. (11): Aflatoxins produced by Aspergillus niger 


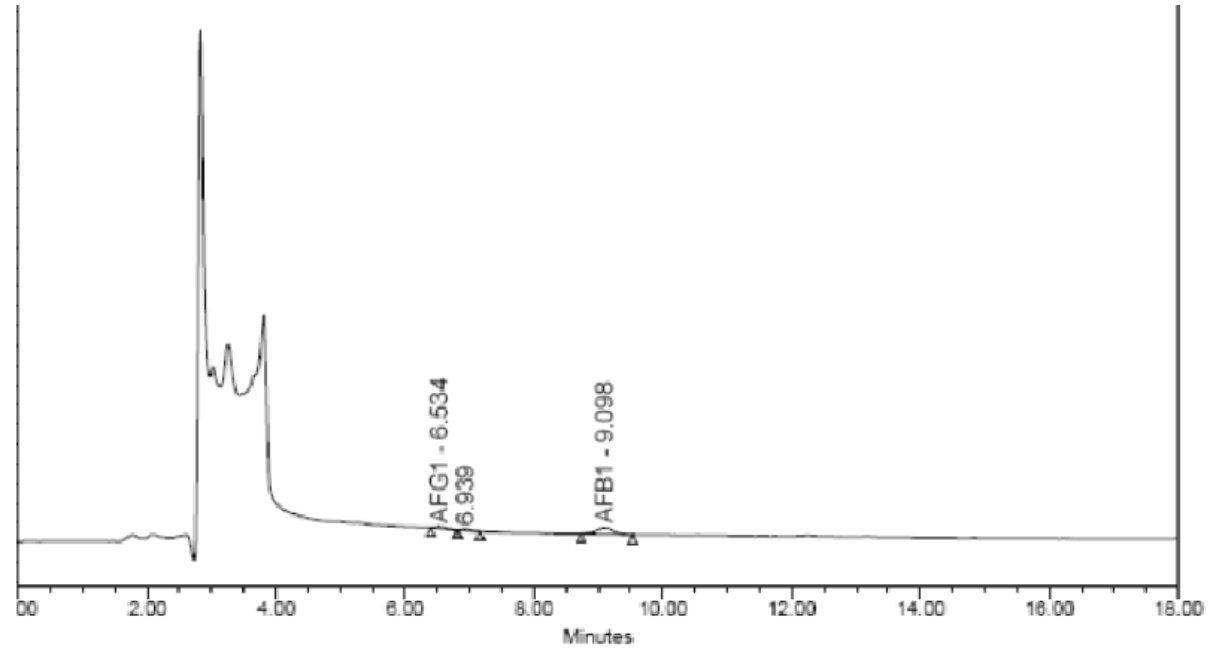

Fig. (12): Aflatoxins produced by Aspergillus parasiticus

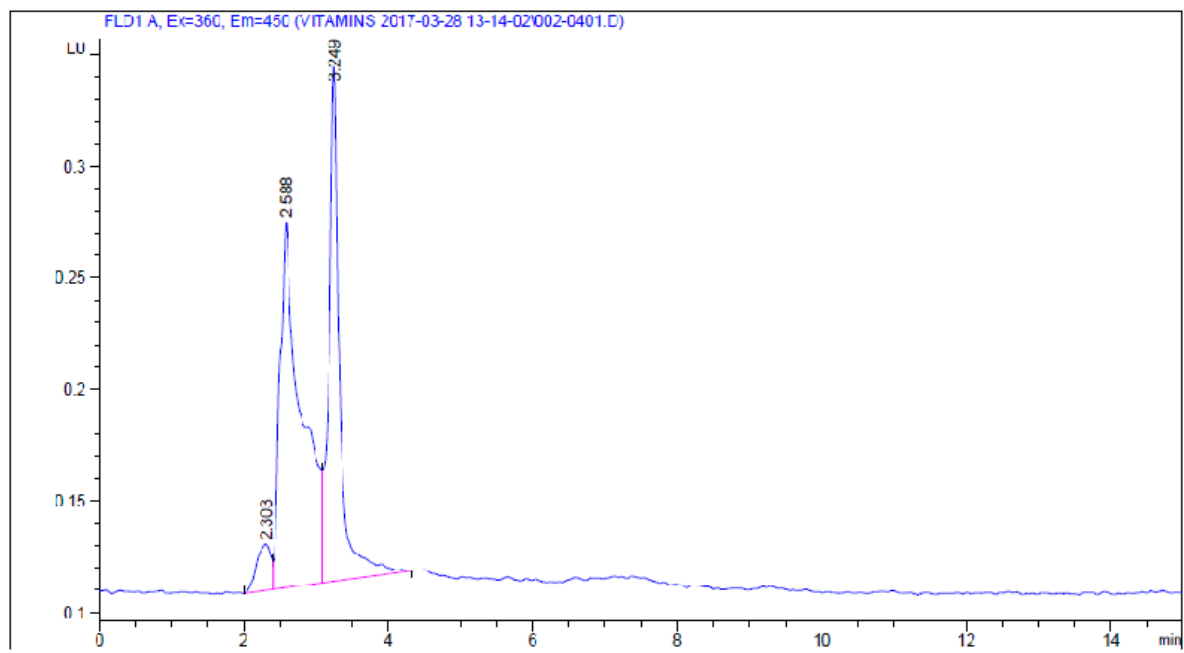

Fig. (13): Aflatoxins produced by Aspergillus terreus

Data in Table (2) reveled that all Aspergillus genera produced mycotoxin except Aspergillus terreus which was negative producer of mycotoxins (AFB1, B2, G1 and G2).

On the other hand, A. flavus produced AFB1, AFB2 and AFG1 with concentrations 0.01 $\mathrm{ng} / \mathrm{ml}, \quad 0.05 \mathrm{ng} / \mathrm{ml}, \quad 0.01 \mathrm{ng} / \mathrm{ml}$, respectively and
AFG2 not detected. A. niger produced AFG1 and AFB2 with concentration 1.00 and $0.01 \mathrm{ng} / \mathrm{ml}$, respectively, while, AFB1 and AFG2 were not detected. A. parasiticus produced AFB1 and AFG1 with concentrations 0.36 and $0.12 \mathrm{ng} / \mathrm{ml}$, respectively while; AFB2 and AFG2 were not detected.

Table (2): Production of mycotoxin from different species of Aspergillus genera

\begin{tabular}{|c|c|c|c|c|c|}
\hline \multirow{2}{*}{ Fungal isolates } & \multicolumn{5}{|c|}{ Mycotoxin (ng/ml) } \\
\hline & AFB1 & AFG1 & AFB2 & AFG2 & Total \\
\hline Aspergillus flavus & 0.01 & 0.01 & 0.05 & ND & 0.02 \\
\hline Aspergillus niger & ND & 1.00 & 0.01 & ND & 1.01 \\
\hline Aspergillus parasiticus & 0.36 & 0.12 & ND & ND & 0.48 \\
\hline Aspergillus terreus & ND & ND & ND & ND & ND \\
\hline
\end{tabular}

$\mathrm{ND}=$ not detected 
Aflatoxins are secondary toxic metabolites produced by certain isolates of Aspergillus flavus, $A$. nomius and $A$. parasiticus however not all isolates are toxigenic.

The ability to synthesize aflatoxins is strain dependent and occurs in the fungal hyphae, conidia and sclerotia. Maximum mycotoxin level are encountered when fungal mycelium reach an optimum level (Varma and Verma, 1987; Baird et al., 2006).

These findings are similar to these of Abramson and Clear (1996) who found that four strains of Aspergillus parasiticus were producing of B1, B2, G1 and G2 aflatoxins, Aspergillic acid and Kajic acid, detection of agar plates of A. flavus and $A$. parasiticus showed aflatoxins after 21 days and it was confirmed by TLC.

Our results are in agreement with Kheiralla (1994) who found that three isolates of Aspergillus flavus produced aflatoxins B1 and B2. One isolate of A. parasiticus produced B1, B2, G1 and G2. Previous studies of Doster et al. (1996) found that the high level of aflatoxins $(>100 \mathrm{ng} / \mathrm{g})$ were detected in $83 \%$ of figs infected by $A$. parasiticus and $38 \%$ of the figs infected by $A$. flavus.

Embaby et al. (2007) reported that Aspergillus niger and $A$. parasiticus were isolated from rotted apricot fruits and found that two isolates of $A$. parasiticus produced one or more of aflatoxins B1, B2, G1 and G2.

Al-Abdalall (2009) found that Aspergillus niger produced aflatoxins $\mathrm{B} 1, \mathrm{~B} 2$ and $\mathrm{G} 2$ in field beans.

\section{REFERENCES}

Abramson, D. and R. M. Clear (1996). A Convenient method for assessing mycotoxin production in cultures of Aspergilli and Penicillia. Journal of Food Protection, 59(6): 642-644.

Agrios, G. N. (2005). Plant Pathology. $5^{\text {th }}$ Edition, Academic Press. New York. 633 pp.

Agwa, O. K., L. N. Ossai-Chidi and C. A. Ezeani (2014). Microbial evaluation of orange fruit juice sold in port Harcout, Nigeria. American Journal of Food Science and Nutrition Research, 1(5): 28-33.

Al-Abdalall, A. (2009). Production of aflatoxins by Aspergillus flavus and Aspergillus niger strains isolated from seeds of pulses. Journal of Food, Agriculture and Environment, 7(2): 33-39.

AOAC (2007). Association of Official Analytical Chemists. Official Methods of Analysis of AOAC International $17^{\text {th }}$ Ed., Nature Toxins. AOAC International, Arlington, Virginia, USA, Chapter 49.

Baird, R. E., R. N. Trigiano, G. Windham, P. Williams, R. Kelley, H. K. Abbas, J. K. Moulton and M. L. Scruggs (2006).
Comparison of aflatoxigenic and non aflatoxigenic isolates of Aspergillus flavus using DNA amplification fingerprinting techniques. Mycopathologia, 161: 93-99.

Barent, H. L. and B. Hunter (1977). Illustrated genera of imperfect fungi. Burgess Publishing Company, Minnesota. 2412 pp.

Bhale, U. N. (2011). Survey of market storage diseases of some important fruits of Osmannabad District (M.S.) India. Science Research Reporter, 1: 88 - 91.

Coviello, R., W. Bentley, T. Michailides, L. Ferguson and B. Westerdahl (2009). UC statewide integrated pest management program. Pest Management Guidelines: fig Publication. 3447 pp.

Doster, M. A., T. J. Michailides and D. P. Morgan (1996). Aspergillus species and mycotoxins in figs from California orchards. Plant Dis., 80: 484-489.

Doster, M. A. and T. L. Michailides (2007). Fungal decay of first-crop and main-crop figs. Plant Dis., 91: 1657-1662.

El-Fadaly, M. H., S. M. El-Kadi, M. N. Hamad and A. A. Habib (2015). Isolation and identification of Egyptian Ras Cheese (Romy) contaminating fungi during ripening period. Journal of Microbiology Research, 5(1):1 -10.

Embaby, E. M., M. M. Abdel-Galil and L. F. Hagagg, (2007). Occurrence of aflatoxins in some rotted apricot fruit in Egypt. Research Journal of Agriculture and Biological Sciences, 3(6): 631-637.

Embaby, E. M., L. F. Hagagg and M. M. AbdelGalil (2012). Decay of some fresh and dry fruit quality contaminated by some mold fungi. Journal of Applied Sciences Research, 8(6): 3083-3091.

Embaby, E. M. and L. F. Hagagg (2014). Citrus fruit decay and its control. Journal of Agriculture Technology, 10(5): 12731288.

Farjood, E. and Z. Banihashemi (2013). Incidence of Aspergillus species and mycotoxins in dried figs in Southern Iran. Iran. J. Plant Path., 48(4): 183-189.

Ferguson, L., T. L. Michailides and H. H. Shorey (1990). The California fig industry. Hortic. Rev., 12: 409-490.

FAOSTAT (2014). Raw fig production in 2014, Crops/World/Regions/Production Quantity from Pick Lists. UN Food and Agriculture Organization Report Statistical Database.

Han, D., S. J. Macdonald, V. Boughtflower and P. Brereton (2004). Simultaneous determination of aflatoxins and ochratoxin $\mathrm{A}$ in food using a fully automated immune affinity column clean up and liquid Chromatography fluorescence detection. Journal of chromatography (A), 1059: 1316. 
Iamanaka, B. T., M. H. Taniwaki, H. C. Menezes, E. Vicente and M. H. Fungaro (2005). Incidence of toxigenic fungi and ochratoxin A in dried fruits sold in Brazil. Food Addit. Contam., 22(12): 1258-1263.

Javanmard, M. (2010). Occurrence of mould counts and Aspergillus species in Iranian dried figs at different stages of production. Journal of Agricultural Science and Technology, 12: 331-338.

Kheiralla, Z. H. (1994). Mycotoxins of corn grains. Egypt Journal of Microbiology, 29(2): 149-157.

Maren, A. K. and I. P. Johan (1988). A Laboratory guide to the common Aspergillus spp. and their teleomorphs. Commnwealth Scientific and Industrial Research Organisation. Division of Food Processing, 116 pp.

Nelson, P. E., T. A. Toussoun and W. F. O. Marasas (1983). Fusarium species: An Illustrated Manual for Identification. Pennsylvania State University Press, University Park. 193 pp.

Oranusi, U. S. and B. Wesley (2012). Microbiological safety assessment of apple fruits (Malus domestica Borkh) sold in Owerri Imo State Nigeria. Advance Journal of Food Science and Technology, 4(2): 97-102.

Pitt, J. I. and A. D. Hocking (2009). Fungi and food spoilage. $3^{\text {rd }}$ ed. London, U.K. Blackie Academic and Professional, 519 pp.

Saadullah, A. A. and S. K. Abdullah (2014). Detection of Aspergillus species in dried fruits collected from Duhok market and study their aflatoxiginic properties. Raf. J. Sci., 25(1): 12-18.

Samson, R. A. and J. Varga (2007). Aspergillus systematics in the genomic era. Studies in Mycology 59. CBS Fungal Biodiversity Centre, Utrecht. The Netherlands.

Sekar, P., N. Yumnam and K. Ponmurugan (2008). Screening and characterization of mycotoxin producing fungi from dried fruits and grains. Advanced Biotech., 7(1): $12-15$.

Singh, D. and R. R. Sharma (2007). Postharvest diseases of fruit and vegetables and their management. In: D. Prasad ( ${ }^{\text {st }}$ Ed. $)$, Sustainable Pest Management. Daya Publishing House, New Delhi, India.

Singh, K., C. Jenz, U. Thron and S. B. Mathur (1991). An illustrated manual on identification of some seed-borne Aspergilli, Fusaria, Penicillia and their mycotoxins. First ed., Danish Government Institute of Seed Pathology for Developing Countries. Ryvangs Alle 78. DK-2900 Hellerup, Denmark and Department of Biotechnology.

Solomon, A., S. Golubowicz, S. Yablowicz, S. Grosman, M. Bergman, H. E. Gottlieb, A. Altman, Z. Kerem and M. Z. A. Flaishman (2006). Antioxidant activities and anthocyanin content of fresh fruits of common fig (Ficuscarica L.). Journal of Agriculture and Food Chemistry, 54: 7717-7723.

Stover, E. D., M. Aradhya, L. Ferguson and c. H. Crisosto (2007). The fig: Overview of an ancient fruit. Hort. Science, 42(5): 10831087.

Tournas, V. H. and E. Katsoudas (2005). Mould and yeast flora in fresh berries, grapes and citrus fruits. International Journal of Food Microbiology, 105: 11-17.

Tzortzakis, N. G. (2009). Impact of cinnamon oilenrichment on microbial spoilage of fresh produce. Innovative Food Science and Emerging Technologies, 10: 97-102.

Varma, S. K. and R. A. B. Verma (1987). Aflatoxin B1 production in orange (Citrus reticulata) juice by isolates of Aspergillus flavus Link. Mycopathologia, 97: 101104.

Watanabe, T. (2010). Pictorial atlas of soil and seed fungi: morphologies of cultured fungi and key to species $3^{\text {rd }}$ ed. Boca Raton, Fl, USA. CRC Press. 


\section{عزل وتعريف الفطريات المسببة لأعفان ثمار التين وتحديد السموم الفطرية الناتجة}

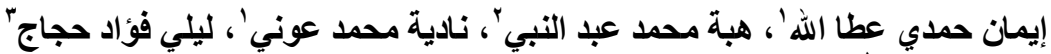

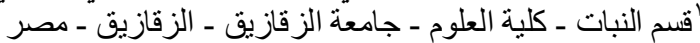

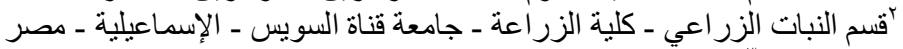

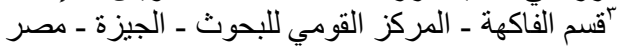

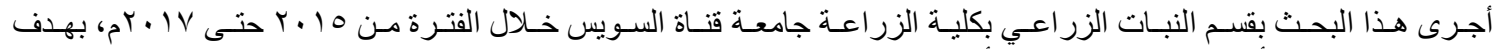

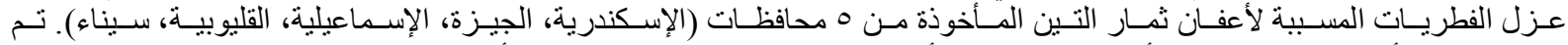

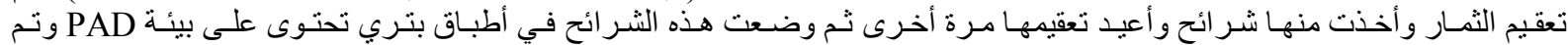

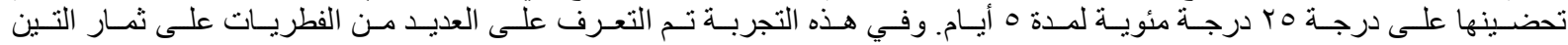
Alternaria tenuis, Aspergillus flavus, Aspergillus niger, Aspergillus parasiticus, Aspergillus terreus, .Botryodiplodia theobromae, Cladosporium sp., Fusarium solani, Penicillium sp. and Rhizopus sp.

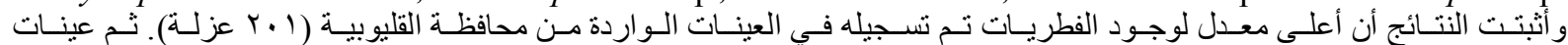

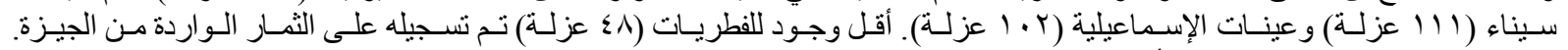

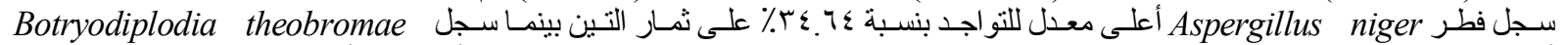

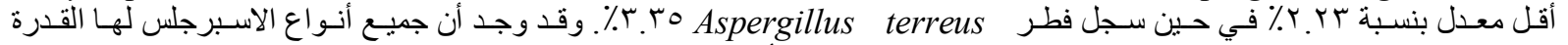

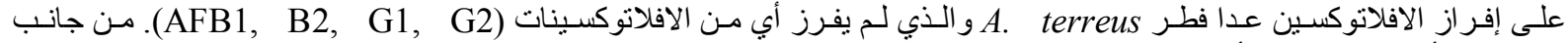

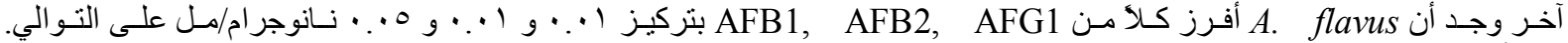

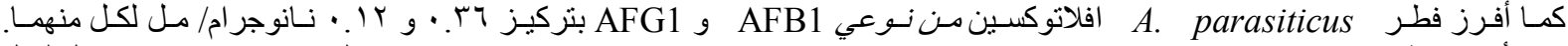

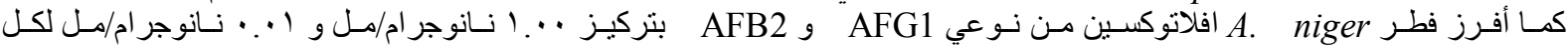

